\title{
2.5 Germany: from feed-in-tariffs to auctions and the question of diverse actors
}

\author{
Dörte Ohlhorst
}

\subsubsection{Summary}

The stakeholder structure of the formerly oligopolistic German electricity market has changed significantly during the energy transition process in the last two decades. The big energy supply companies have lost high market shares to smaller, heterogeneous actors that generate renewable electricity. Both the structure of electricity generating technologies and the ownership structure of the facilities are increasingly decentralised. In this chapter about Germany, the term 'decentralised' is used in the context of community-scale renewable electricity generation and ownership.

The increasingly decentralised system has advantages in terms of resilience, social acceptance, democratic participation in the use of universal goods, and the development of value added in municipalities and regions. This chapter describes how decentralised renewable energy in the hands of communities and citizens has developed in Germany. It elaborates on how the political framework has recently changed, which actors have gained influence and which effects can be expected from the changes in the funding regime regarding decentralisation, local and regional development, democratisation of energy business, the variety of actors and stakeholders, as well as regarding the involvement of citizens in renewable energy supply.

\subsubsection{Decentralised citizen energy in Germany}

Although primary energy consumption is still dominated by fossil fuels (about 79 per cent in 2018) and some nuclear energy (6.4 per cent in 2018), Germany

\section{How to cite this book chapter:}

Ohlhorst, D. 2020. Germany: from feed-in-tariffs to auctions and the question of diverse actors. In: Burger, C., Froggatt, A., Mitchell, C. and Weinmann, J. (eds.) Decentralised Energy - a Global Game Changer. Pp. 82-100. London: Ubiquity Press. DOI: https:// doi.org/10.5334/bcf.f. License: CC-BY 4.0 
aims to obtain 60 per cent of its total energy (final energy consumption) and 80 per cent of its electricity generation from renewables by 2050 . The government has goals for phasing out nuclear by 2022 and simultaneously decarbonising the economy by reducing greenhouse gas emissions by 80 to 95 per cent of 1990 levels by 2050. This transformation is known as the 'Energiewende' (BMU/BMWI 2011), which contrary to popular opinions, is more than just a reaction to the Fukushima nuclear accident.

The beginnings of what is now known as 'Energiewende' date back decades. The transformation was strongly driven from the bottom up. Social movements starting in the late 1960s, such as the peace movement with regard to nuclear weapons, the anti-nuclear power movement, and the environmental movement triggered a change in awareness in large parts of German society. These movements were closely linked to the events of the oil, nuclear, and environmental crises of the 1970s and 1980s (e.g. oil price crises in 1973 and 1979-1980; nuclear accidents in Three Mile Island in 1979 and Chernobyl in 1986; smog and air pollution, especially in coal mining regions and large cities). They mobilised significant resistance against the prevailing policy positions and economic conventions of the time, and activated social engagement for structural changes in energy policy and the supply system. With the founding of the German Green Party (1980) the topic was carried into the political system. Decades of critical social debates about the existing energy policy, starting in the late 1960s and continuing into the present, have led to a counter-proposal to conventional energy supply and resulted in its transformation. The strong desire of many citizens to be concretely involved in the energy transition can only be understood in light of this history (Schreurs 2008).

In Germany, renewables accounted for less than 12 per cent of electricity consumption in 2006. At the end of 2017, they accounted for 38.5 per cent, a materially important expansion achieved in just a few years. Decentralised renewable energies, supported or initiated by citizens, made a significant contribution to this success. Many citizens in Germany have the desire to be involved in the value creation and employment of the energy transition (EWSA 2015; Dunker \& Mono 2013). Financial participation - as an active shareholder or passive donor - provides an opportunity for profitable investments. From the ownership of renewable generation facilities local added value can be generated and jobs as well as apprenticeship training positions can be created. A further component of participation is an active citizen engagement in the sense of not only a financial but also a conceptual initiative to implement renewable energy projects.

In Germany, citizens have organised themselves to initiate and operate renewable energy projects. Currently, almost half of the renewable electricity generation capacity subsidised by the Renewable Energy Sources Act (EEG) (except for offshore wind) is in the hands of small private investors. These actors include individuals, households, energy cooperatives, civil law partnerships, limited liability companies or limited partnerships, decentralised initiatives in 
municipalities and regions, farmers and civil wind farms. These diverse forms of citizen energy ('Bürgerenergie') are an important driver for the dynamics of the energy transition. Moreover, citizen energy encourages more diverse acceptance and support for renewables and thus increases the stability of the German renewable energy sector (BBEn 2014; Zuber 2014; Debor 2014; Müller \& Holstenkamp 2015; Ott \& Wieg 2014, see also country report on Denmark).

$\S 3$ (15) EEG 2017 (Renewable Energy Sources Act 2017) defines a citizen energy company as an entity,

- 'Which consists of at least ten natural persons with voting right,

- in which at least 51 per cent of the voting rights are held by natural persons which live in the urban or rural district in which the onshore wind energy installation is to be erected,

- in which no member or shareholder of the undertaking holds more than 10 per cent of the voting rights of the undertaking' (Renewable Energy Sources Act 2017).

\section{Installed renewable capacity by owner groups 2016}

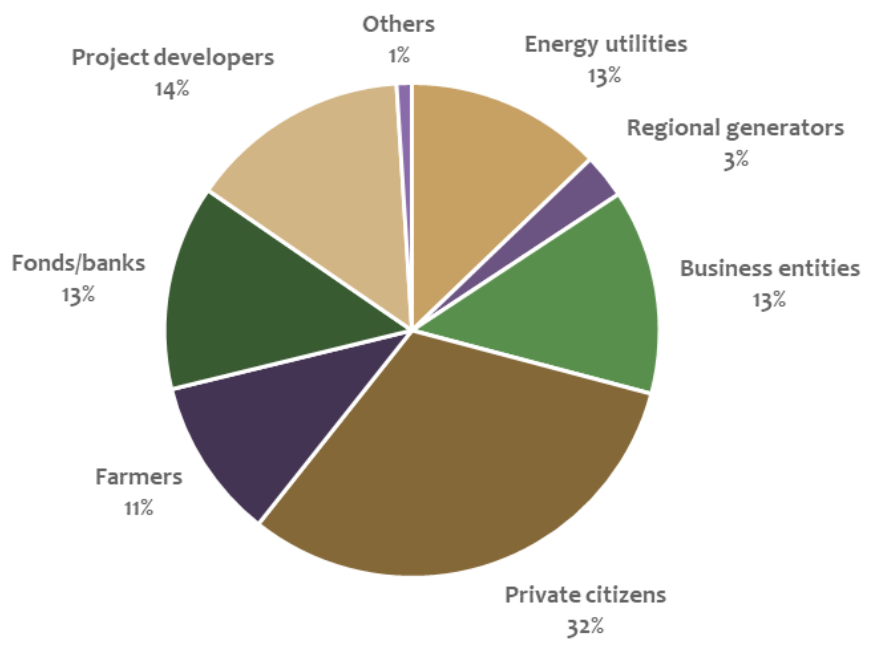

Figure 12: Installed capacity of renewable energy by owner group in Germany in 2016.

Source: Author's contribution based on figures published by trend:research $2018^{15}$

${ }^{15}$ The distribution of ownership to these groups may change in the future due to the shift from fixed feed-in tariffs to tenders for renewable projects. The number of new start-ups of energy cooperatives has fallen by 60 per cent in 2014 due to uncertainties with the new funding system and because the obligatory direct marketing for generating facilities with $500 \mathrm{kWp}$ or more makes the entry less attractive (Kahla et al. 2017). 
Cooperatives and companies in which small private investors hold at least 50 per cent are summarised under the term 'citizen energy', see figure 12, (trend: research \& Leuphana University of Lüneburg 2013). Cooperative models are a particular legal form: on the one hand they are an economic actor, and on the other a civil society actor. Energy cooperatives have a democratic legal structure, in which the members are protected from the dominance of majority owners. Each member, regardless of the level of participation, has one vote in the General Assembly and has a say on the use of resources. Members to a large extent come from the locality or region. The deposits are typically long-term investments. Investors have some protection against financial loss, because each member is only liable for their deposits. Secondly, each cooperative must belong to an auditing association, through which the finances of the cooperative are regularly checked. The cooperative business model is usually long term and requires less return on the investment than other business models with high short-term profit goals. The debt ratio is lower, compared to other legal forms, and the control by supervisory board members and members is often more intense. It is true that cooperatives are not safe from bankruptcy, but this happens less frequently to cooperatives than to conventional companies. Profits are often reinvested in the cooperative goals. The interest on cooperative deposits, though, is lower compared to the return to the investors on their deposits in stocks and risky bonds. ${ }^{16}$

Citizen energy is characterised by a high degree of identification with the local energy supply because most of the electricity is produced close to the consumption points in the neighbourhood (Zuber 2014). ${ }^{17}$ The commitment and investment of citizens represents a key driving force of the Energiewende: citizen energy has a market share of at least 31.5 per cent of the installed renewable electricity capacity in Germany (see Figure 12; trend:research 2018; Zuber 2014). Between 2007 and 2014 the total number of registered energy cooperatives in Germany grew from 94 to 973 and has since increased more than tenfold. In the years 2011 (195 newly registered cooperatives), 2012 (187), and 2013 (172), the increase in energy cooperatives reached an all time high (Müller \& Holstenkamp 2015). In the year 2012, cooperatives invested $€ 1.67$ billion in renewables, and built up electricity generation capacities with an output of 933 MW (DGRV 2015; Kemfert \& Schäfer 2012; trend: research \& Leuphana University Lüneburg 2013). The German energy cooperatives founded since 2006 have about 130,000 members (DGRV 2015; Janzig 2015). ${ }^{18}$ Hubert Waiger from

${ }^{16}$ http://www.sozialinvestieren.de/blog/insolvenzsicherste-rechtsformgenossenschaften-bleiben-unangefochten-sieger/

17 There are also German cooperatives that are committed to the repurchase of local electricity networks or the concession for the operation of local networks. However, these are not directly affected by the amendment to the EEG.

${ }_{18}$ Not all energy cooperatives are also citizen energy cooperatives. The DGRV data and the database from Degenhart, Holstenkamp, and Müller are not directly comparable. 
the Federation for Environment and Nature Conservation Germany (BUND) called this commitment the 'Largest civil movement in the history of our country. ${ }^{19}$ Cooperatives are seen as a possible economic model for eco-social transformation and as a learning environment for civil societal and democratic values (Walk 2014).

The high number of renewable energy projects in the hands of citizens, organisations, and affiliated companies has led to a pluralistic stakeholder and ownership structure in the German power generation market. Farmers, public utilities, and small and medium enterprises complete the spectrum of power generators, which has expanded enormously since the expansion of renewables (Moss, Becker \& Naumann 2014).

Previously, the electricity market was divided between a few large energy utilities. The German government repeatedly declares the target to maintain actor diversity in energy transition efforts and that regional and local efforts towards a low-carbon energy transition are welcome. This also corresponds to the coalition agreement between the CDU/CSU parliamentary party (Christian Democrats) and the SPD parliamentary party (Social Democrats), which promises that the local communities will be more involved in the added value of renewable energy facilities and the opportunities for project participation of citizens will be improved.

One advantage of raising capital through the private investment of citizens is the lower yields that are deemed acceptable by this group, as opposed to larger companies (Mono 2013). The enhanced decentralised participation in financing can then ensure a large part of the investments necessary for the expansion of renewable energy. However, the mobilisation of private capital required to meet investment needs requires suitable investment models and incentives that need to be set by governance (Jacobs et al. 2014; WBGU 2012).

\subsubsection{Drivers for - and against - decentralised renewable energy in Germany}

The national funding regime has acted as a central driver in the development of renewable energy in Germany. With the Electricity Feed-In Act and its successor, the Renewable Energy Sources Act (EEG), a priority for grid connection and electricity feed-in as well as fixed feed-in tariffs for renewables was introduced. The Electricity Feed-In Act, passed in 1990, was one of the first laws in Europe that obliged public energy utilities to purchase and remunerate

The former only covers energy cooperatives founded from 2006; the latter recognise registered energy cooperatives.

19 Public Hearing of the Committee on Environment, Nature Conservation, Building and Nuclear Safety; June 4th, 2014. https://www.bundestag.de/dokumente/text archiv/2014/eeg-novelle/281434. 
renewable electricity on a yearly fixed basis. During the 1990s, not only the renewable electricity support policy, but also the general legal framework for the energy sector was important for the promotion of renewable energy in Germany. The Renewable Energy Sources Act was adopted in 2000, replacing the Electricity Feed-In Act and establishing a new, pioneering support policy with improved investment security for generators: while under the Electricity Feed-In Act compensation rates were expressed as percentages of average customer tariffs, the new rates were now fixed for 20 years. The EEG has been amended regularly since the year 2000. The feed-in tariffs set out in the law have been the central prerequisite for the expansion of renewables during the following 15 years. The renewable energy share in electricity supply increased dynamically - today it covers more than one third of the power supply. Due to the declining, but guaranteed feed-in tariffs, investments in renewables were able to be deployed with low risks for investors.

Besides the funding regime, a strong citizen engagement favoured the production of decentralised renewables in Germany. Citizen engagement is motivated by a desire for autonomy, freedom of action, control, and for shaping one's own living conditions. People have relatively high confidence in the objectives and values of citizen initiatives, whereas there is increasing distrust towards state actors and short-term-profits-oriented economic operators, and the non-transparent relations between them (Büscher \& Sumpf 2014; Sumpf 2014). One motivation for self-generated electricity is (partial) energy independence, and for some households it is even the idea of a self-sufficient power supply. A consumer survey in 2013 showed that six per cent of all Germans are so-called prosumers - they do not only consume, but also generate electricity (both for own consumption and for sale, Verbraucherzentrale Bundesverband 2013).

The decentralised initiatives are improving local value added income and employment options (Deutscher Landkreistag 2014a). In 2012, citizen energy projects brought a (gross) value of $€ 5.3$ billion to the respective regions (Hauser et al. 2015). Adverse local developments like declining municipal revenues due to shrinking population numbers can be compensated through wind, solar and biogas projects (Deutscher Landkreistag 2014b). About 113,600 permanent jobs, particularly in the field of plant operation, are assigned to citizen renewable energy projects (Hauser et al. 2015).

It is assumed that participation in citizen energy projects increases not only local acceptance of renewable energy plants, but also the experience of selfefficacy as well as social inclusion of vulnerable people (Tews 2018). However, acceptance depends on whether the implementation of the projects correspond with the ideas of citizens about democratic decision-making processes, transparency and participation, sufficient decision options, an inclusive planning culture, and an adequate distribution of costs and benefits (Mono 2013; Bauknecht, Vogel \& Funcke 2015; Schweizer et al. 2014; 100 prozent erneuerbar stiftung 2012; Bovet \& Lienhoop 2015). 
Due to recent changes in the political and legal framework however, decentralised initiatives appear to be at risk. The changes have resulted in the termination of price-based feed-in tariffs and premium systems. Moreover, a shift from an optional to a mandatory direct marketing system for new renewable energy plants has taken place. The obligatory direct marketing presents new challenges for suppliers and operators.

\subsubsection{Change of funding regime by amendment of the Renewable Energy Sources Act (Erneuerbare Energien-Gesetz)- EEG in 2014}

With an amendment to the EEG in 2014, the government set the course for the introduction of a tendering model that replaces the system of fixed feed-in remuneration (e.g. Kahles 2014). Previously, the level of the feed-in tariff (differentiated by technology and based on forecasts) was determined by parliament, but the actual cost could differ from the forecasts. As a result, the level of financial support could prove to be excessive or too low. According to the German Government, the introduced bidding procedure will address this matter.

In the new procedure, annual quotas of renewable electricity generating capacity are tendered via auctions. First experiences with the tender model where gained in a pilot phase for photovoltaic ground-mounted systems (Deutscher Bundestag 2014). From 2017 onwards, the compensation rates for all renewables are determined via a tender procedure. ${ }^{20}$ Only those market participants that have been selected by the tender process are allowed to build renewable energy plants. The aim is to carry out the construction of new renewable energy installations as economically as possible and in accordance with European state aid rules. Small systems with a capacity below one MW, however, are not subject to the tendering procedure.

The change in the funding mechanism was carried out not only due to national but also supranational pressure by the European Commission (Beermann \& Tews 2016; Tews 2014; Vogelpohl et al. 2017). The Commission considers quota systems as the most appropriate instrument for an integrated energy market. Its harmonisation efforts were intensified at the end of 2013, as the European Commission revised state aid guidelines and consequently initiated an infringement procedure against the German funding system with fixed feed-in tariffs. Large energy utilities and actors pursuing a market-liberal policy in the European Commission supported this policy.

Not only on the European level, but also in Germany, the control of costs and capacities of renewables has been increasingly debated. Influential players

${ }^{20}$ The feed-in tariff, which is determined through the tender procedure, is adapted to the dynamics of renewable energy expansion when the expansion has exceeded or fallen below the corridor of annual quotas during the reference period ('principle of breathing lid'). 
argued that the promotion of renewable energy should be better adapted to the existing market structure (Wassermann, Reeg \& Nienhaus 2015). By adopting and fundamentally changing the funding system, the German federal government (a grand coalition) thus not only pursued the aim of decarbonising the electricity production in compliance with the EU law, but also had the intention to improve the predictability of the expansion of renewable energy dynamics and to achieve the government's renewable energy development objectives in, what the government argued was a more cost-effective way. In contrast, the critics of the EEG amendment argued that these objectives could also have been achieved with the existing funding regime. They are afraid that the expansion of renewable energies in Germany will stagnate and, consequently, the climate protection targets cannot be met. The government, however, argued that the new funding scheme can promote more market and technology competition and at the same time avoid the protection for specific technologies.

\subsubsection{Decentralised citizen energy and actor diversity at risk?}

It is becoming apparent that new risks are arising from the new procedure that was introduced by the German Bundestag, initiated by the Ministry of Economics. It is feared that with the conversion of a regime with fixed feed-in tariffs to an auction based system the financially strong supra-regional providers will have improved opportunities to increase their market share. The results of the pilot bidding rounds on ground mounted PV (2014-2016) verified the concerns regarding a decline in the diversity of actors and the exclusion of small players (Tews 2018). For decentralised, small projects with local character, the amendment constitutes a much bigger challenge (EnKlip 2015; Kahl, Kahles \& Müller 2014; Leuphana Universität of Lüneburg \& Nestle 2014; BNetzA 2015). The maintenance of actor diversity is a politically defined goal ${ }^{21}$ that is both explicitly mentioned in the coalition agreement and in the EEG 2014 ( $\$ 2$ para. 5 sentence 3 ). A specific focus on citizen-based energy companies is officially explained and justified in \$36g EEG 2017: 'In particular, locally anchored citizen energy companies have made a significant contribution to the necessary acceptance of new on-shore wind energy projects. Without this acceptance, the expansion of wind energy cannot be achieved in the planned amount' (Deutscher Bundestag 2016, author's translation). Nevertheless, many scientists and practical actors consider the new funding regime a serious threat to the continued commitment of the small, local and civic actors (Niederberger \& Wassermann 2015; Tews 2018). It is feared that competition

${ }^{21}$ See $\$ 2$ para 5 sentence 3 EEG 2014: 'When switching to the tender procedure, actor diversity in renewable electricity generation is to be obtained' (translated by author). 
decreases and the plurality of actors cannot be obtained in the renewable energy market, because:

Participation in a tendering procedure requires high operating expenses, is time consuming, complex, and costly. In coping with the complex requirements large providers have significant advantages over small ones. The transaction costs incurred can be intercepted more easily by larger companies (Leuphana Universität Lüneburg \& Nestle 2014; Kahl, Kahles \& Müller 2014; Klessmann 2014). Citizen energy actors usually find it more difficult to spread the risk or protect themselves against the risks through their own private capital. They have a lower credit rating and hardly any opportunities for interim financing. This is demonstrated by international experience with tendering mechanisms (BWE 2014).

There is uncertainty to tenderers whether the contract is awarded in an auction participation. Accordingly, uncertainty for investors about the expected returns increases (Grießhammer \& Bergmann 2015; Nestle 2015). ${ }^{22}$ The return on capital investment equity for investors decreases because the final price they receive for the renewables is lower due to rising costs and additional risks (Grau, Neuhoff \& Tisdale 2015). Even if an actor has been awarded the contract, it may occur that the site-specific costs are higher and revenues are lower than projected. As a consequence, the plant may not be realised. In this case, significant penalties may be accrued (Ecofys 2014; Hauser et al. 2014; Hauser et al. 2015).

In the course of compulsory direct marketing, plant operators have to either bring their electricity to market themselves (this can also be to regional markets), or they can employ external services. This results in costs for marketing, forecasting, and profile service. Furthermore, the operator (electricity supplier) incurs many obligations, including the sale of excess capacity and the purchase of additional electricity in the event of equipment failure or under-production, in order to ensure security of supply for customers. The effort and cost can be problematic, particularly for civil energy projects and energy cooperatives, because they generally are run by volunteers and have fewer opportunities to diversify risk (BEE 2015; Leuphana Universität Lüneburg \& Nestle 2014). The obligatory direct marketing increases the financial risk for plant operators. They must compensate for uncertainties in marketing with risk premiums. Moreover, it is assumed that banks require long-term power purchase agreements with economically powerful direct marketers for project finance. As part of the credit assessment of the direct marketers, it is possible that large marketers are favoured.

A new characteristic of the tender procedure is not only the determination of the level of compensation via competing offers, but also the waning influence

${ }^{22}$ Also changes of the Investment Code and concession law have contributed to uncertainty (Kahl et al. 2014). 
of the parliament: previously, the actual level of remuneration was set through the feed-in tariffs in the Renewable Energy Sources Act, which was developed and changed by parliament. The tender procedure is performed by the Grid Agency, allowing no influence of parliament on the compensation rate.

Overall, the new funding system is characterised by a lower market openness, lower actor plurality, and lower investment security than the previously applied principle of fixed feed-in tariffs. It is therefore feared that tenders and the obligatory direct marketing represent a massive market entry barrier for citizen energy operators. Under the new system, they are hardly able to compete against larger competitors and hardly able to afford the huge transaction costs for developing legally sound and competitive bids (BEE 2015).

There is some evidence for these concerns: since 2014, the formation of new energy cooperatives has been rapidly declining. According to the German Genossenschafts- und Raiffeisenverband (German Cooperative and Raiffeisen Confederation, DGRV), the number of newly registered energy cooperatives in 2014 declined by 60 compared to the previous year. In 2014, only 54 energy cooperatives were founded, whereas in 2011, 167 such enterprises were launched nationwide, see figure 13 (Müller \& Holstenkamp 2015).

This sharp decline in growth illustrates the effects of the amendment to the Renewable Energy Sources Act (Grießhammer \& Bergmann 2015). Investment activities of the existing energy co-operatives have dropped significantly.

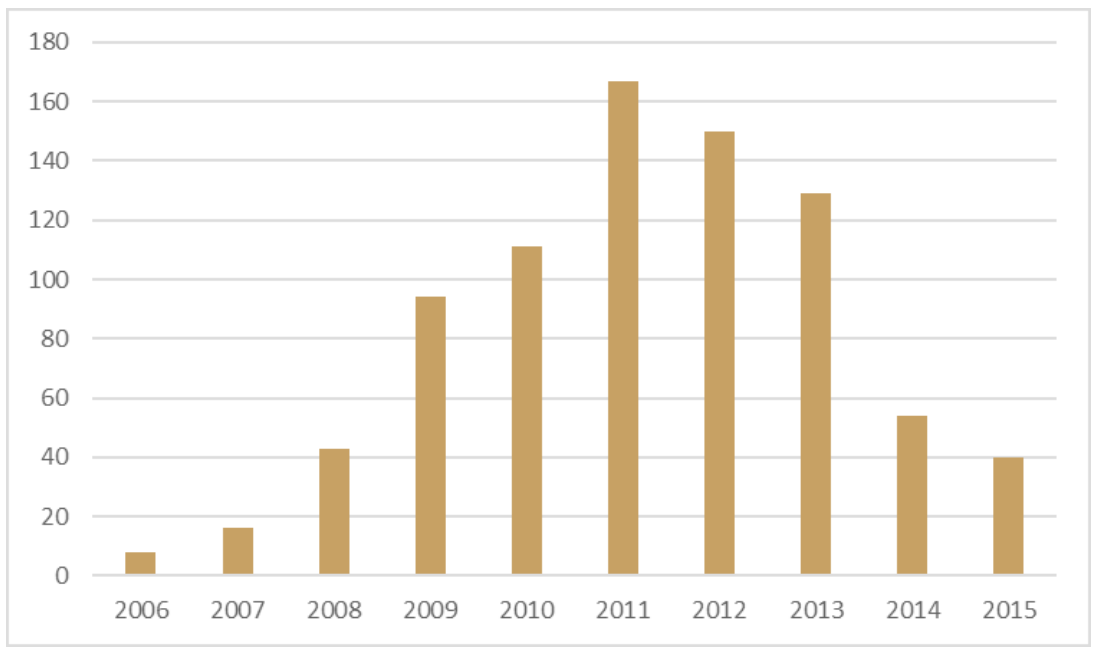

Figure 13: Start-up of energy cooperatives 2006-2015.

Source: DGRV 23

${ }^{23}$ German Cooperative and Raiffeisen Confederation, DGRV; https://www.erneuerb areenergien.de/buerger-muessen-teil-der-energiewende-bleiben/150/437/88921/. 
Surprisingly, in the first auctions in 2017, the majority of the awards were given to citizens' energy companies. The bidders made use of the specific rules for citizen energy: they could take part in the bidding procedure without having a construction permit, and could make use of the longer time span between awards and realisation of the project deadline (up to 4 to 5 years). However, it turned out that the successful bidders, privileged as citizens' energy companies, were set up by a small number of professional project developers, contractors or service providers (Tews 2018). They transformed their projects and found constructions that made them look like citizens' energy projects because they were adapted to the official rules of citizen energy. As such, the project developers could make use of the respective privileges in the bidding procedure. Moreover, they were - at least organisationally - assigned to one single project developer (Bundesnetzagentur 2017). The exceptional rules - intended to support rather unprofessional and small citizen-based projects - were used by business actors in an economically rational way to meet the legal requirements of a citizen energy company. This leads to the need to re-amend the Renewable Energy Sources Act if the goal of preserving the variety of actors is to be achieved and if 'real' citizens' energy projects should be addressed. It also leads to the need of a clear definition of the term 'citizen energy'.

According to the German Renewable Energy Federation (BEE), environmental organisations and green electricity providers, tenders change the level playing field to the detriment of the variety of actors and generate new risks that are difficult to manage. In order to maintain the diversity of actors, the BEE repeatedly demands that projects up to $18 \mathrm{MW}$ should be excluded from the tendering procedure. This approach proposed by the BEE has been confirmed by the EU Competition Commissioner - a derogation to this extent would be permissible under European law (BEE 2016). Until now, only projects up to an installed capacity of one megawatt are excluded from the tendering procedure. It is proposed that new citizen 's energy projects should receive an administratively fixed remuneration without having to go through the tender procedure, because with adequate project sizes, a regional balance between supply and demand and a high acceptance they produce the best power solutions for local and regional markets (Hannen \& Enkhardt 2015).

\subsubsection{Conclusions}

Germany has multiple goals for the implementation of the energy turnaround: not only a decarbonisation of the electricity supply by 2050, but also a costefficient power supply and a diversity of electricity-producing actors. The fulfilment of the latter goals is important because efficient energy generation at a reasonable price as well as electricity production by community and citizen energy projects helps to gain acceptance for the large-scale transformation with high transition costs and new technologies emerging all over the landscape. As 
the number of wind farms across the country increases, the acceptance factor becomes increasingly important.

The recent replacement of fixed feed-in tariffs by a technology-specific and volume based auction system, not introduced by a regulator, but by the German Bundestag, represents a fundamental change in the funding regime of the German Renewable Energy Sources Act. The government launched the new funding model (auction system), even though experiences in other countries have shown that auction systems often did not reach the desired results and costminimising effects (AEE 2014; Agora 2014; Ecofys 2014; Hauser et al. 2014). It is not clear whether the European guidelines actually require opting out of the feed-in tariff. The legal situation would probably allow wider exemptions for smaller market participants than is provided for in the amended Renewable Energy Sources Act (Münchmeyer, Kahles \& Pause 2014). Therefore, it is assumed that the German Government used the EU requirements to realise its own national reform ideas (Vogelpohl et al. 2017). It is expected that the modification of the funding regime will not lead to a return towards centralised power generation technologies, but to a more centralised ownership structure of generating plants.

In the first tender rounds in 2017, almost exclusively citizens' energy companies were awarded. This was a great surprise for all who accompanied the design of the tender scheme in the new Renewable Energy Sources Act. With less than six Euro cents per $\mathrm{kWh}$, the bidding prices where about one cent below the previous average remuneration - and are thus very low. Evidence shows, professional investors have applied under the cover of alleged citizens' firms, who were able to construct their bidding company according to the privileging exception rules for citizen energy.

In the 2019 tender rounds for wind turbines, the level of competition was lower than ever before. A trend that has already been observed over several rounds in 2018 has been continued. In January 2019, with a tendered volume of 700 megawatts (MW), only 72 bids totalling 499 megawatts were submitted. A total of 67 bids with a volume of 476 megawatts were awarded a supplement. Only eleven of these supplements went to citizens' energy companies. The competitive level for the second round of calls in May 2019, with a 55\% signing, had a new worrying dimension. Again, insufficient bids were submitted to cover the tendered amount of $650 \mathrm{MW}$. Of the $650 \mathrm{MW}$ tendered, only $270 \mathrm{MW}$ could be awarded for the construction of new wind turbines. The reasons for this dramatic decline in the expansion of wind energy are manyfold: the complexity of the tendering process, increasing citizen protests against wind energy, a great uncertainty in the market and high penalties in case of failed implementation. The capping of tenders at a level of 2.5 gigawatts and the debate over new regulations regarding the minimum mandatory distances to residential buildings caused uncertainty. In addition, more and more citizens are resisting wind turbines in their neighbourhood - and often take legal action. A project that has been awarded a contract, has a time frame of only two to a maximum 
of two and a half years to actually realise the wind farm. Otherwise the bidder faces penalties ranging from 150,000 to 200,000 euros per turbine.

It remains unclear whether the future design of the tender rounds actually serves the achievement of the desired wind power capacities on the one hand and the preservation of the diversity of actors on the other - and thus the protection of operating models with local investors, local and regional value added, mixed ownership structure, distributed voting rights, a participatory legal structure, and social inclusiveness. It is possible that the different energy policy sub-processes and the legal framework in Germany will reduce the citizens' commitment to the energy turnaround and lead to more centralised ownership structures of the generating plants. However, there will continue to be citizen engagement for renewable energies in the future, because it is increasingly cost effective to produce electricity with sustainable resources. Therefore, organisational and institutional niches are likely to be found for citizens' cooperatives. In addition, the possibility of self-supply with renewable electricity may increasingly be used in the future. If, however, the detour through the tendering procedure slows down the dynamics of citizen participation, this poses a risk for the acceptance of the energy projects in the electricity sector. A diversity of stakeholders, acceptance, participation and active involvement of citizens are essential success factors for the energy supply in Germany, because these factors help place the energy transition on a broader footing within society.

\subsubsection{References}

100 prozent erneuerbar stiftung. (2012), Akzeptanz für Erneuerbare Energien. Akzeptanz planen, Beteiligung gestalten, Legitimität gewinnen (Kurzfassung). Retrieved February 10, 2019, from http://100-prozent-erneuerbar. de/2012/09/akzeptanz-fur-erneuerbare-energien-\%E2\%80\%93-100-prozent-erneuerbar-stiftung-veroffentlicht-umfangreichen-leitfaden/

AEE Agentur für Erneuerbare Energien. (2014), Studienvergleich: Finanzierungsinstrumente für Strom aus Erneuerbaren Energien. Metaanalyse von Vorschlägen für die zukünftige Finanzierung von Strom aus Erneuerbaren Energien. AEE: Berlin.

Agora Energiewende. (2014), Ausschreibungen für Erneuerbare Energien. Berlin.

Bauknecht, D., Vogel, M. \& Funcke, S. (2015), Energiewende - Zentral oder dezentral? Diskussionspapier im Rahmen der Wissenschaftlichen Koordination des BMBF Förderprogramms: Umwelt- und Gesellschaftsverträgliche Transformation des Energiesystems. Ökoinstitut Freiburg, 28.07.2015.

BBEn. (2014), Energiewende braucht Bürgerenergie (Positionspapier). Retrieved from http://www.buendnis-buergerenergie.de/fileadmin/user_upload/ downloads/Positionspapiere/BBEn_Positionspapier_EEG-Novelle.pdf. 
BEE. (Bundesverband Erneuerbare Energie e.V.) (2015), Regierungspläne für Solarausbau bremsen die Energiewende. Pressemitteilung des BEE vom 21.01.2015. http://www.verbaende.com/news.php/Regierungsplaene-fuerSolarausbau-bremsen-die-Energiewende? $\mathrm{m}=101121$.

BEE. (Bundesverband Erneuerbare Energie e.V.) (2016), BEE-Bilanz zum EEG 2017. Deutliche Drosselung der Energiewende, leichte Verbesserungen im Detail. Retrieved February 10, 2019, from https://www.bee-ev.de/home/ presse/mitteilungen/detailansicht/bilanz-zum-eeg-2017-deutliche-drosselung-der-energiewende-leichte-verbesserungen-im-detail/

Beermann, J. \& Tews, K. (2017), Decentralised laboratories in the German energy transition. Why local renewable energy initiatives must reinvent themselves. Journal of Cleaner Production (Special Volume: The opportunities and roles of experimentation in addressing climate change), 69, 125-134.

BNetzA. (2015), Hintergrundpapier. Ergebnisse der zweiten Ausschreibungsrunde für PV-Freiflächenanlagen vom 1. August 2015. Bonn: Bundesnetzagentur.

Bovet, J. \& Lienhoop, N. (2015), Trägt die wirtschaftliche Teilhabe an Flächen für die Windkraftnutzung zur Akzeptanz bei? Zum Gesetzesentwurf eines Bürger- und Gemeindebeteiligungsgesetzes in Mecklenburg-Vorpommern unter Berücksichtigung von empirischen Befragungen. Zeitschrift für Neues Energierecht 16/3, 227-234.

Büscher, C. \& Sumpf, P. (2014, July), Trust, distrust and confidence in energy system transformation. Paper presented at XVIII ISA World Congress of Sociology "Facing an unequal world: challenges for global sociology", Yokohama, Japan.

Bundesnetzagentur. (2017), Pressemitteilung 15.08.2017. Ergebnisse der zweiten Ausschreibung für Wind an Land. Retrieved fromhttps://www.bunde snetzagentur.de/SharedDocs/Pressemitteilungen/DE/2017/15082017_ WindAnLand.html

BWE. (2014), Stellungnahme zum Entwurf eines Gesetzes zur grundlegenden Reform des Erneuerbare-Energien-Gesetzes und zur Änderung weiterer Bestimmungen des Energiewirtschaftsrechts (BT Drs. 18/1304). Berlin: Bundesverband Windenergie.

Debor, S. (2014), The socio-economic power of renewable energy cooperatives in Germany: results of an empirical assessment. Wuppertal Papers, No. 187 (Working Paper). Retrieved from https://www.econstor.eu/dspace/ bitstream/10419/97178/1/785254935.pdf

Deutscher Bundestag. (2014), Entwurf eines Gesetzes zur grundlegenden Reform des Erneuerbare-Energien-Gesetzes und zur Änderung weiterer Bestimmungen des Energiewirtschaftsrechts. 18. Wahlperiode. Drucksache 18/1304. Berlin: Deutscher Bundestag.

Deutscher Bundestag. (2015), Auswirkungen der Novelle des ErneuerbareEnergien-Gesetzes 2014. Antwort der Bundesregierung auf die Kleine Anfrage der Abgeordneten Dr Julia Verlinden, Oliver Krischer, Christian 
Kühn (Tübingen), weiterer Abgeordneter und der Fraktion BÜNDNIS 90/ DIE GRÜNEN, Drucksache 18/5774. 18. Wahlperiode. Drucksache 18/5898. Berlin: Deutscher Bundestag.

Deutscher Bundestag. (2016): Gesetzentwurf der Fraktionen der CDU/CSU und SPD. Entwurf eines Gesetzes zur Einführung von Ausschreibungen für Strom aus erneuerbaren Energien und zu weiteren Änderungen des Rechts der erneuerbaren Energien. Drucksache 18/8860, 21 June 2016, see http:// dip21.bundestag.de/dip21/btd/18/013/1801304.pdf

Deutscher Landkreistag. (2014a), Energiewende ist für ländlichen Raum. Chance und Herausforderung zugleich - Nachbesserungen beim EEG notwendig. Retrieved from http://www.landkreistag.de/presseforum/ pressemitteilungen/1351-pressemitteilung-vom-19-maerz-2014.html

Deutscher Landkreistag. (2014b), Regionale Wertschöpfung durch erneuerbare Energien. Handlungsstrategien für Landkreise zur Initiierung einer regionalen Kreislaufwirtschaft. Unter Mitarbeit von Institut für angewandtes Stoffstrommanagement (IfaS). Retrieved from http://www.landkreistag.de/ images/stories/publikationen/bd-120.pdf

DGRV Deutscher Genossenschafts- und Raiffeisenverband e.V. (2015), Energiegenossenschaften. Ergebnisse der DGRV-Jahresumfrage (zum 31.12.2014). Retrieved from https:/www.dgrv.de/webde.nsf/7d5e59ec98e72442c125 6e5200432395/418a5acd4479ba4ec1257e8400272bec/\$FILE/DGRV-Jahresumfrage.pdf

Dunker, R. \& Mono, R. (2013), Bürgerbeteiligung und erneuerbare Energien. Kurz-Studie von Beteiligungsprojekten in Deutschland durch die 100 prozent erneuerbar Stiftung. Berlin. Retrieved from http://100-prozent-erneuerbar. de/wp-content/uploads/2013/07/Buergerbeteiligung-und-ErneuerbareEnergien_100pes.pdf

Ecofys. (2014), Design features of support schemes for renewable electricity. A report compiled within the European project "Cooperation between EU MS under the Renewable Energy Directive and interaction with support schemes". Retrieved from https://ec.europa.eu/energy/sites/ener/files/ documents/2014_design_features_of_support_schemes.pdf, accessed 10 February 2019

Engerer, H. (2014), Energiegenossenschaften in der Energiewende. DIW Roundup - Politik im Fokus. 17. Juli 2014. Retrieved from http://www.diw. de/de/diw_01.c.470180.de/presse/diw_roundup/energiegenossenschaften_ in_der_energiewende.html.

EnKlip. (2015), Ausschreibungen für Erneuerbare Energien - überwindbare Hemmnisse für Bürgerenergie?, see http://www.buendnis-buergerenergie. de/fileadmin/user_upload/Buergerenergie_und_Ausschreibungen_BBEn_ 2015.pdf.

EWSA Europäischer Wirtschafts- und Sozialausschuss. (2015), Die Energie von Morgen erfinden - Die Rolle der Zivilgesellschaft bei der Erzeugung 
erneuerbarer Energie. Retrieved from http://www.renewableuk-cymru. com/wp-content/uploads/2015/01/CivilSocietyRenewableEnergy.pdf

Grau, T., Neuhoff, K. \& Tisdale, M. (2015), Verpflichtende Direktvermarktung von Windenergie erhöht Finanzierungskosten. DIW Wochenbericht Nr. 21.2015, pp. 503-508. Berlin: Deutsches Institut für Wirtschaftsforschung.

Grießhammer, R. \& Bergmann, M. (2015), Wissenschaftliche Koordination des BMBF-Förderprogramms: „Umwelt- und gesellschaftsverträgliche Transformation des Energiesystems. Entwicklungsportfolio, Synthese, Partizipationsmethoden, Transfer. Freiburg: Öko-Institut.

Hannen, P. \& Enkhardt, S. (2015, November 26), EEG-Reform: Gemeinsame Ausschreibungen für PV-Dachanlagen und Solarparks geplant. pv magazine.

Hauser, E., Weber, A., Zip, A. \& Leprich, U. (2014), Bewertung von Ausschreibungsverfahren als Finanzierungsmodell für Anlagen erneuerbarer Energienutzung. Endbericht. Für IZES GmbH, Saarbrücken. Retrieved from http:// www.bee-ev.de/Publikationen/IZES2014-05-20BEE_EE-Ausschreibungen_ Endbericht.pdf

Hauser, E., Hildebrand, J., Dröschel, B., Klann, U., Heib, S. \& Grashof, K. (2015), Nutzeneffekte von Bürgerenergie. Retrieved from http://blog.green peace-energy.de/wp-content/uploads/2015/09/IZES-2015_09_10_B percentC3 percentBCE-Nutzen_Endbericht.pdf.

Hochloff, P., Sandau, F. \& Bofinger, S. (2014), Bürgerenergiewende oder Industrieprojekt? Eine Beleuchtung des Diskurses zur Ausrichtung der Energiewende. Retrieved from http://www.polsoz.fu-berlin.de/polwiss/ forschung/systeme/ffu/forschung-alt/projekte/laufende/11_energytrans/ konferenz2014/programm/2-iwes-Hochloff.pdf

Jacobs, D., Peinl, H., Gotchev, B., Schäuble, D., Matschoss, P., Bayer, B., Kahl, H., Kahles, M., Müller, T. \& Goldammer, K. (2014), Ausschreibungen für erneuerbare Energien in Deutschland - Ausgestaltungsoptionen für den Erhalt der Akteursvielfalt. Retrieved from http://www.iass-potsdam.de/ sites/default/files/files/working_paper_ausschreibungen_final.pdf

Janzig, B. (2015), Bürgerprojekte in Deutschland. Politik grätscht dazwischen. Berlin: die tageszeitung (taz), 21.7.2015.

Kahl, H., Kahles, M. \& Müller, T. (2014), Anforderungen an den Erhalt der Akteursvielfalt im EEG bei der Umstellung auf Ausschreibungen. Würzburger Berichte zum Umweltenergierecht. Würzburg. Retrieved from http://www. stiftung-umweltenergierecht.de/fileadmin/Bilder/Newsletter/WueBericht_ 9_Akteursvielfalt_final.pdf

Kahla, F., Holstenkamp, L., Müller, J.R. \& Degenhart, H. (2017), Entwicklung und Stand von Bürgerenergiegesellschaften und Energiegenossenschaften in Deutschland. Working Paper Series in Business and Law, No. 27.

Kahles, M. (2014), Ausschreibungen als neues Instrument im EEG 2014. Stiftung Umweltenergierecht, Würzburger Berichte zum Umweltenergierecht, Vol. 6. Retrieved from http://www.stiftung-umweltenergierecht.de/fileadmin/ 
pdf_aushaenge/Aktuelles/WueBericht_6_Ausschreibungen_im_EEG_ 2014_2014-07-16.pdf.

Kemfert, C. \& Schäfer, D. (2012), Finanzierung der Energiewende in Zeiten großer Finanzmarktinstabilität. In: DIW Wochenbericht, Nr. 31, 2012, p. 3-14. Berlin: Deutsches Institut für Wirtschaftsforschung.

Klessmann, C. (2014), Wie lassen sich Akteursvielfalt und Bürgerenergieprojekte im Ausschreibungsdesign berücksichtigen? Fachgespräch Grüne Bundestagsfraktion am 24.09.2014. Berlin: Ecofys. Retrieved from http://oliver-krischer. eu/fileadmin/user_upload/gruene_btf_krischer/2014/3_Ecofys_Ausschrei bungsworkshop_Gruene-BT.pdf.

Leuphana Universität Lüneburg \& Nestle, U. (2014), Marktrealität von Bürgerenergie und mögliche Ausweitungen von regulatorischen Eingriffen. Studie im Auftrag des Bündnis Bürgerenergie e.V. und des Bund für Umwelt und Naturschutz Deutschland e.V. (BUND). Retrieved from http://www.enklip. de/resources/Studie_Marktrealitaet+von+Buergerenergie_Leuphana_ FINAL_23042014.pdf

Mono, R. (2013), Umsetzung der Energiewende durch Bürgerbeteiligung. Retrieved from http://www.leuphana.de/fileadmin/user_upload/PERSONAL PAGES/_ijkl/kahla_franziska/1._Rene_Mono.pdf

Moss, T., Becker, S. \& Naumann, M. (2014), Whose energy transition is it, anyway? Organisation and ownership of the Energiewende in villages, cities and regions. Local Environment. The International Journal of Justice and Sustainability. 12/2015, 1547-1563.

Münchmeyer, H., Kahles, M. \& Pause, F. (2014), Erfordert das europäische Beihilferecht die Einführung von Ausschreibungsverfahren im EEG? Hg. v. Stiftung Umweltenergierecht (SUER). Würzburger Berichte zum Umweltenergierecht, Vol. 5. Retrieved from http://www.stiftung-umweltenergierecht. de/fileadmin/pdf_aushaenge/Aktuelles/WueBericht__5_Beihilferecht_ Erfordernis_Ausschreibungen_final_2014-07-16.docx.pdf

Müller, J.R. \& Holstenkamp, L. (2015), Zum Stand von Energiegenossenschaften in Deutschland. Aktualisierter Überblick über Zahlen und Entwicklungen zum 31.12.2014. Leuphana Universität Lüneburg, Arbeitspapierreihe Wirtschaft and Recht Nr. 20. Retrieved from http://www.buendnis-buergerenergie.de/fileadmin/user_upload/downloads/Studien/Studie_Zum_ Stand_von_Energiegenossenschaften_in_Deutschland_Leuphana.pdf

Nestle, U. (2015), Ausschreibungen für Erneuerbare Energien: Überwindbaren Hemmnisse für Bürgerenergie? Eine wissenschaftliche Expertise von EnKliP. Im Auftrag des Bündnis Bürgerenergie e.V. Kiel. Kiel: EnKliP

Niederberger, M. \& Wassermann, S. (2015), Die Zukunft der Energiegenossenschaften: Herausforderungen und mögliche Ansätze für zukünftige Geschäftsmodelle. Energiewirtschaftliche Tagesfragen, 65( 8), 55-57.

Ott, E. \& Wieg, A. (2014), Please, in My Backyard — die Bedeutung von Energiegenossenschaften für die Energiewende. In C. Aichele \& O.D. Doleski 
(Eds), Smart Market. Vom Smart Grid zum intelligenten Energiemarkt (pp. 829-841). Wiesbaden: Springer Fachmedien

Schreurs, M. A. (2008), From the bottom up: local and subnational climate change politics. The Journal of Environment and Development, 17 (4), 343-355.

Schweizer, P.-J., Renn, O., Köck, W., Bovet, J., Benighaus, C., Scheel, O. \& Schröter, R. (2014), Public participation for infrastructure planning in the context of the German "Energiewende”. Utilities Policy. 43, Part B, 206-209.

Sumpf, P. (2014), Energiewende und Vertrauen (Energy Transition and Trust). GAIA 23/3, pp. 287-288.

Tews, K. (2014), Europeanization of energy and climate policy: new trends and their implications for the German energy transition process. FFU-Report 03-2014. Berlin: Environmental Policy Research Centre, Freie Universität Berlin.

Tews, K. (2018), The crash of a policy pilot to legally define community energy. Evidence from the German Auction Scheme. Sustainability 2018, 10(10), 3397.

Trendresearch \& Leuphana Universität Lüneburg. (2013), Definition und Marktanalyse von Bürgerenergie in Deutschland. Im Auftrag der Initiative „Die Wende - Energie in Bürgerhand” und der Agentur für Erneuerbare Energien. Bremen/Lüneburg: Trendresearch and Leuphana Universität Lüneburg.

Trendresearch. (2018), Eigentümerstruktur: Erneuerbare Energien. Entwicklung der Akteursvielfalt, Rolle der Energieversorger, Ausblick bis 2020. Bremen: Trendresearch.

Vogelpohl, T., Ohlhorst, D., Bechberger, M. \& Hirschl, B. (2017), German renewable energy policy - independent pioneering versus creeping Europeanization? In I. Solorio \& H. Jörgens (Eds), The EU renewable energy policy: challenges and opportunities (pp. 45-64). Cheltenham: Edward Elgar.

Verbraucherzentrale Bundesverband. (2013), Vom Verbraucher zum Stromerzeuger. TNS Emnid Umfrage im Auftrag der vzbv. Retrieved from http:// www.vzbv.de/pressemitteilung/vom-verbraucher-zum-stromerzeuger

Walk, H. (2014), Energiegenossenschaften: neue Akteure einer nachhaltigen und demokratischen Energiewende? In A. Brunnengräber \& M.R. Di Nucci (Eds), Im Hürdenlauf zur Energiewende (pp. 451-464). Wiesbaden: Springer Fachmedien.

Wassermann, S., Reeg, M. \& Nienhaus, K. (2015), Current challenges of Germany's energy transition project and competing strategies of challengers and incumbents: The case of direct marketing of electricity from renewable energy sources. Energy Policy 76, 66-75.

WBGU Wissenschaftlicher Beirat der Bundesregierung Globale Umweltveränderungen. (2012), Finanzierung der globalen Energiewende. Berlin. Retrieved from http://www.wbgu.de/fileadmin/templates/dateien/veroeffentlichungen/politikpapiere/pp2012-pp7/wbgu_pp7_dt.pdf 
Zuber, F. (2014), Der Bürger als Treiber der Energiewende: Vom passive Konsumenten zum aktiven Gestalter der lokalen Energieversorgung? Bündnis Bürgerenergie e.V. Retrieved from http://www.polsoz.fu-berlin.de/polwiss/ forschung/systeme/ffu/forschung-alt/projekte/laufende/11_energytrans/ konferenz2014/programm/2-buergerenergie-Zuber.pdf 